\title{
Pengaruh Intensitas Penggunaan Media Sosial Terhadap Prestasi Belajar Siswa Kelas X Di Sma Muhammadiyah 1 Palangka Raya
}

\author{
Ressa Kahayanti ${ }^{1}$, Offeny ${ }^{2}$, Ahmad Saefulloh $^{3}$ \\ 1,2,3 Universitas Palangka Raya \\ Email : ressakahayanti1409@yahoo.com, offeny.pky58@gmail.com, saefulloh@fkip.upr.ac.id
}

\begin{abstract}
Abstrak
Penelitian ini bertujuan mengetahui pengaruh intensitas penggunaan media sosial terhadap prestasi belajar siswa kelas X di SMA Muhammadiyah 1 Palangka Raya. Jenis penelitian ini adalah penelitian kuantitatif dengan metode korelasional, populasi meliputi seluruh siswa kelas X SMA Muhammmadiyah 1 Palangka Raya yang berjumlah 145 siswa. Sampel yang digunakan adalah 60 siswa, teknik pengambilan sampel dalam peneitian ini dengan probability sampling yaitu simple random sampling dimana sampel terdiri dari beberapa kelas. metode pengumpulan data dilakukan dengan angket dan dokumentasi. Dari uji coba instrumen intensitas penggunaan media sosial di dapat valid 34 dari 40 instrumen. Hasil uji reliabilitas dengan alfa cronbach intensitas penggunaan media sosial di dapat $\mathrm{r}_{\mathrm{xy}} 0.932>\mathrm{r}_{\text {tabel }} 0,330$ dan untuk prestasi belajar siswa didapat $r_{\mathrm{xy}} 0.943>\mathrm{r}_{\text {tabel }} 0,330$. Hasil penelitian adalah: 1 . Intensitas penggunaan media sosial oleh siswa kelas $\mathrm{X}$ di SMA Muhammadiyah 1 Palangka Raya adalah sedang ditunjukan oleh nilai mean (rata-rata) 92,82, nilai median (nilai tengah) 74,78, nilai modus (nilai yang sering muncul) 78,78, standar deviasi 5,18. Masuk dalam kategori rendah sebanyak 18 siswa atau 30\%, kategori sedang sebanyak 16 siswa atau 27\%, dan kategori tingi sebanyak 26 siswa atau 43\%. 2. Prestasi belajar siswa kelas X di SMA Muhammadiyah 1 Palangka Raya adalah sedang ditunjukan oleh nilai mean (rata-rata) 82,75, nilai median (nilai tengah) 82,90, nilai modus (nilai yang sering muncul) 84,95 , standar deviasi 2,51. Masuk dalam kategori rendah sebanyak 7 siswa atau $12 \%$, kategori sedang sebanyak 53 siswa atau $88 \%$, dan kategori tingi sebanyak 0 siswa atau $0 \%$. 3. Ada pengaruh intensitas penggunaan media sosial terhadap prestasi belajar siswa kelas X di SMA Muhammadiyah 1 Palangka Raya. Dengan koefisien korelasi sebesar 0,211 hal ini menunjukan pengaruh intensitas penggunaan media sosial terhadap prestasi belajar siswa kelas X di SMA Muhammadiyah 1 Palangka Raya adalah rendah.
\end{abstract}

Kata Kunci : Intensitas Penggunaan, Media Sosial, Prestasi Belajar Siswa.

\begin{abstract}
This study aims to determine the effect of the intensity of the use of social media on the learning achievement of class X students at SMA Muhammadiyah 1 Palangka Raya. This type of research is a quantitative study with a correlational method, the population includes all class X students of SMA Muhammmadiyah 1 Palangka Raya, totaling 145 students. The sample used was 60 students, the sampling technique in this research was probability sampling, namely simple random sampling where the sample consisted of several classes. the data collection method was done by using a questionnaire and documentation. From the trial of the intensity of the use of social media, 34 of the 40 instruments can be valid. Reliability test results with alpha cronbach intensity of use of social media obtained rxy $0.932>r$ table 0.330 and for student achievement obtained rxy $0.943>r$ table 0.330 . The results of the study are: 1 . The intensity of the use of social media by class $X$ students at SMA Muhammadiyah 1 Palangka Raya is being shown by the mean (average) value of 92.82 , the median value (middle value) 74.78, the mode value (the value that is appears frequently) 78.78, standard deviation 5.18. The low category was 18 students or $30 \%$, the medium category was 16 students or $27 \%$, and the high category was 26 students or $43 \%$. 2. The learning achievement of class X students at SMA Muhammadiyah 1 Palangka Raya is being shown by the mean (average) 82.75 , the median value (middle value) 82.90 , the mode score (the value that often appears) 84.95 , standard deviation of 2.51 . It was included in the low category as many as 7 students or $12 \%$, the medium category was 53 students or $88 \%$, and the high category was 0 students or $0 \% .3$. There is an influence on the intensity of the use of social media on the learning achievement of class X students at SMA Muhammadiyah 1 Palangka Raya. With a correlation coefficient of 0.211 , this shows the effect of the intensity of the use of social media on the learning achievement of class X students at SMA Muhammadiyah 1 Palangka Raya is low.
\end{abstract}

Keyword : Intensity of Use, Social Media, Student Learning Achievement. 


\section{PENDAHULUAN}

Adanya media sosial selain mempunyai pengaruh positif tentu juga mempunyai penggaruh negatif terhadap dunia pendidikan terutama dalam proses pembelajaran, berkenaan dengan prestasi belajar siswa (Chaidar 2014) menyatakan bahwa "Perubahan dalam pola pembelajaran amat sanggat dibutuhkan untuk melakukan pembaharuan dalam sebuah sistem pembelajaran konvensional yang dinilai sudah usang dan tidak relevan dengan dinamika perkembangan zaman yang berkembang semakin cepat dan intensif, dipicu oleh perkembangan ilmu pengetahuan dan teknologi. Teknologi informasi dan komunikasi dalam pembelajaran berperan sebagai penghubung dalam pelaksanaan transfer ilmu pengetahuan tanpa sama sekali menghilangkan model awal pembelajaran yang berlangsung secara tatap muka di dalam kelas. Pemanfaatan teknologi informasi dan komunikasi dalam pembelajaran dilakukan dalam rangka meningkatkan efektifitas dalam pelaksanaan proses pembelajaran yang pada akhirnya diharapkan dapat meningkatkan hasil belajar siswa serta mutu individu para peseta didik dalam hal penggunaan teknologi secara lebih tepat dan bermanfaat".

Setiap siswa diharapkan mampu menggunakan media sosial dengan bijak serta dapat mengendalikan diri dari pengaruh negatif penggunan media sosial yang dapat menurunkan prestasi belajar, peran orang tua serta guru menjadi penting dalam mengawasi penggunaan media sosial oleh siswa sehingga sesuai dengan tujuan pendidikan nasional. Berdasar UU No. 20 Pasal 3 (Republik Indonesia 2003) Tentang Sistem Pendidikan Nasional, menyatakan "Pendidikan nasional berfungsi untuk mengembangkan kemampuan dan membentuk watak serta peradaban bangsa yang bermartabat dalam rangka mencerdaskan kehidupan bangsa, bertujuan untuk berkembangnya potensi peserta didik agar menjadi manusia yang beriman dan bertakwa kepada Tuhan Yang Maha Esa, berahlak mulia, sehat, berilmu, cakap, kreatif, mandiri dan menjadi warga negara yang demokratis serta bertanggung jawab". Berdasar pengamatan langsung yang peneliti lakukan saat menjalani Praktek Pengalaman Lapangan (PPL-II) di SMA Muhammadiyah 1 Palangaka Raya peneliti menemukan bahwa siswa dibebabkan menggunakan smarthphone selama proses pembelajaran. Dengan smarthphone banyak informasi yang bisa siswa dapatkan dari media sosial terutama berkaitan dengan materi pembelajaran, banyak sumber yang bisa siswa jadikan bahan belajar tidak hanya dari buku paket dan guru, sehingga dapat memfasilitasi siswa untuk belajar mandiri. Selain penggaruh positif diatas ada juga penggaruh negatif dari penggunaan media sosial oleh siswa seperti menyebabkan ganguan penglihatan akibat terlalu sering menatap smarthphone untuk mengakses media sosial maupun bermain game, motivasi belajar dari buku paket kurang, mudah bosan apabila tidak membuka media sosial atau bermain game (ketergantungan), kurang kreatif mengerjakan tugas dari guru hanya meniru yang sudah ada di media sosial, tidak fokus mengikuti pembelajaran sebab diam-diam mengakses media sosial.Berdasarkan uraian dari latar belakang masalah tersebut peneliti tertarik untuk mengadakan penelitian yang berjudul "Pengaruh Intensitas Penggunaan Media Sosial Terhadap Prestasi Belajar siswa Kelas X di SMA Muhammmadiyah 1 Palangka Raya.

\section{METODOLOGI}

Jenis penelitian ini merupakan penelitian kuantitatif dengan menggunakan metode korelasional. "Penelitian korelasi bertujuan untuk menemukan ada tidaknya pengaruh intensitas penggunaan media sosial terhadap prestasi belajar siswa dan apabila ada, berapa eratnya pengaruh serta berarti atau tidak pengaruh itu" (Arikunto 2002).

Dalam penelitian ini menggunakan teknik pengumpulan data berupa dokumentasi dan angket untuk mengetahui pengaruh intensitas penggunaan media sosial terhadap prestasi belajar siswa kelas $\mathrm{X}$ di SMA Muhammadiyah 1 Palangka Raya. Subjek dalam populasi ini adalah siswa kelas X di SMA Muhammadiyah 1 Palangka Raya yang berjumlah 145 siswa dengan sampel yaitu 60 siswa.

Teknik pengambilan sampel dalam penelitian ini dengan probability sampling yaitu simple random sampling yang menurut (Sugiyono 2019) "dikatakan simple (sederhana) karena pengambilan anggota 
sampel dari populasi dilakukan secara acak tanpa mempehatikan strata yang ada dalam populasi itu". Teknik analisis dalam penelitian kuantitatif ini adalah dengan Uji Validitas dan Reliabilitas, Mean, Median, Modus, Standar Deviasi dan Uji Prasyarat.

\section{HASIL DAN PEMBAHASAN}

SMA Muhammadiyah terletak di Jl. RTA. Milono Km. 1,5 Palangka Raya yang di dirikan pada tanggal 12 Desember 1977 dibawah naungan Majlis/ bagian Pendidikan Pengajaran dan Kebudayaan dengan Surat Keputusan Pimpinan Pusat Muhammadiyah Majlis Pendidikan Pengajaran dan kebudayaan No: 4154/II-1/KTG-77/1983 dengan nama SMA Muhammadiyah. Menyatakan bahwa SMA Muhammadiyah 1 Palangka Raya terakreditasi AMAT BAIK (A) berdasarkan Sertifikat Akreditasi Sekolah yang di keluarkan oleh Badan Akreditasi Sekolah Nomor 34/Bas.Prov/Ktg/VI pada tanggal 31 Juli 2005.

\section{Intensitas Penggunaan Media Sosial}

Penelitian ini dilakukan di kelas X SMA Muhammadiyah 1 Palangka Raya tahun pelajaran 2019/2020, jumlah siswa yang menjadi responden adalah 60 siswa dengan metode angket yang terdiri atas 34 pertanyaan. Dari penelitian di peroleh nilai tertinggi 134 dan nilai terendah 42 . Adapun analisis hasil distribusi data sebagai beikut:

Tabel 5. Distribusi Frekuensi Data Intensitas Penggunaan Media Sosial

\begin{tabular}{llll}
\hline Interval & Frekuensi & Presentase & Kategori \\
\hline $42-73$ & 18 & $30 \%$ & Rendah \\
$74-105$ & 16 & $27 \%$ & Sedang \\
$106-135$ & 26 & $43 \%$ & Tinggi \\
jumlah & 60 & $100 \%$ & \\
\hline
\end{tabular}

Dari data di atas diketahui intensitas penggunaan media sosial siswa termasuk dalam kategori rendah sebanyak 18 siswa (30\%) berada pada interval 42-73, kategori sedang sebanyak 16 siswa (27\%) berada pada interval $74-105$, dan kategori tinggi sebanyak 26 siswa (43\%) Berada Pada Interval $74-105$.

Gambar 3. Diagram Intensitas Penggunaan Media Sosial

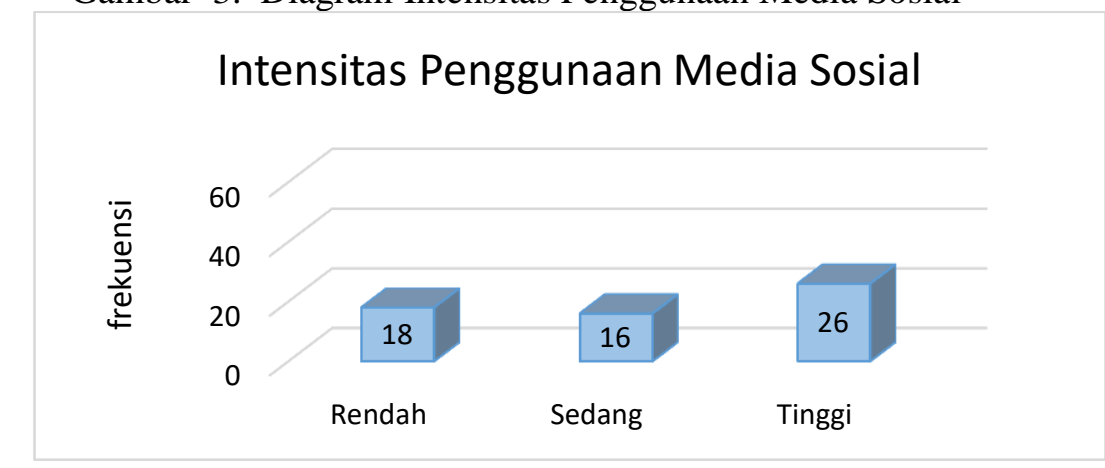

Berdasarkan diagram diatas dapat di simpulkan bahwa intensitas penggunaan media sosial oleh siswa paling banyak termasuk dalam kategori tinggi. 


\section{Prestasi Belajar Siswa}

Data prestasi belajar siswa diperoleh dari nilai rapot yang disebarkan ke 60 reponden dalam bentuk angket. Adapun analisis hasil distribusi data sebagai beikut:

\begin{tabular}{|c|c|c|c|}
\hline Interval & Frekuensi & Presentase & Kategori \\
\hline $71-80$ & 7 & $12 \%$ & Rendah \\
\hline $81-90$ & 53 & $88 \%$ & Sedang \\
\hline $91-100$ & 0 & $0 \%$ & Tinggi \\
\hline Jumlah & 60 & $100 \%$ & \\
\hline
\end{tabular}

Berdasarkan data di atas di ketahui prestasi belajar siswa termasuk dalam kategori rendah sebanyak 7 siswa (12\%) berada pada interval 71-80, kategori sedang sebanyak 53 siswa (88\%) berada pada interval 81-90, dan kategori tinggi sebanyak 0 siswa (0\%) berada pada Interval 91-100.

Gambar 4. Diagram Prestasi Belajar Siswa

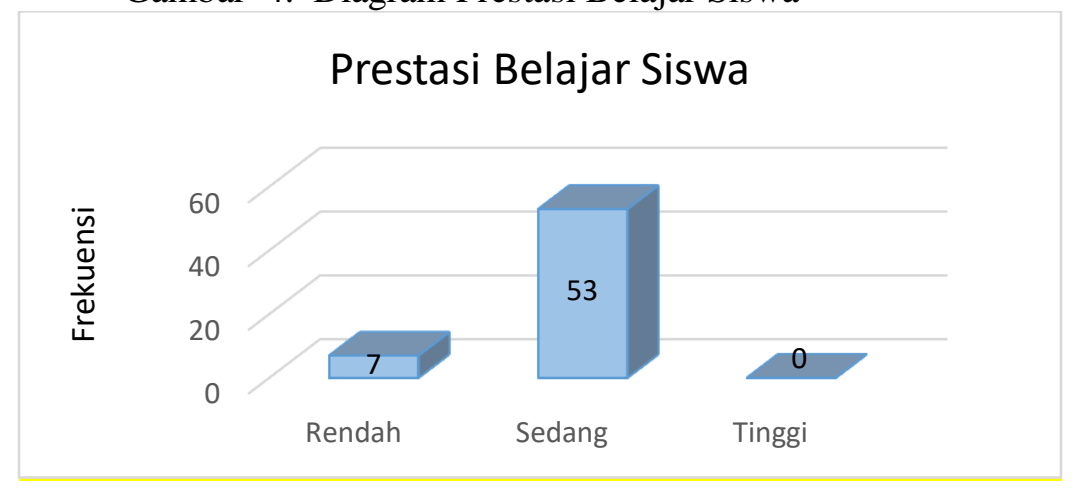

Berdasarkan diagram diatas dapat di simpulkan bahwa prestasi belajar siswa paling banyak termasuk dalam kategori sedang.

\section{a. Uji Asumsi Klasik}

1. Uji Normalitas

Pengujian di lakukan untuk mengetahui apakah variable penelitian berdistribusi normal atau tidak . Uji normalitas ini menggunakan Teknik uji liliefors serta bantuan program SPPSS versi 20. Adapun kriteria variable berdistribusi normal jika nilai $\mathrm{L}_{\text {hitung }}<\mathrm{L}_{\text {tabel }}$ atau nilai signifikansi $>0,05$. Berdasarkan hasil uji normalitas untuk variabel intensitas penggunaan media sosial didapat nilai sig sebesar 0,200>0,05 sedang untuk variabel prestasi belajar siswa didapat nilai sig sebesar $0,200>$ 0,05 . Dapat disumpulkan bahwa sampel dari kedua variabel berdstribusi normal.

2. Uji Hipotesis

Pengujian ini di lakukan dengan teknik analisis product moment dengan SPSS versi 20. Adapun kriteria $\mathrm{H}_{\mathrm{O}}$ ditolak jika signifikansi $(\mathrm{p})<0,05$ dan $\mathrm{H}_{\mathrm{A}}$ diterima jika signifikansi $(\mathrm{p})>0,05$. Berdasar hasil analisis didapat nilai korelasi sebesar 0,211 dan signifikansi 0,105>0,05.

Pernyataan diatas menunjukan bahwa $\mathrm{H}_{\mathrm{A}}$ diterima atau ada pengaruh intensitas penggunaan media sosial terhadap prestasi belajar siswa kelas X di SMA Muhammadiyah 1 Palangka Raya. 


\section{b. Analisis Data}

Adapun analisis data dapat dilihat pada tabel sebagai berikut:

Tabel 7. Analisis Data Intensitas Penggunaan Media Sosial

\begin{tabular}{ll}
\hline Analisis Data & $\begin{array}{l}\text { Intensitas Penggunaan } \\
\text { Media Sosial }\end{array}$ \\
\hline Mean & 92,82 \\
Median & 74,78 \\
Modus & 78,78 \\
Standar Deviasi & 5,18 \\
\hline
\end{tabular}

Dari tabel diatas didapat bahwa rata-rata (mean) intensitas penggunaan media sosial yaitu 92,82 , sedang nilai tengah (median) sebesar 74,78, dan nilai yang sering muncul (modus) yaitu 78,78, serta nilai standar deviasinya adalah 5,18 .

Tabel 8. Analisis Data Prestasi Belajar Siswa

\begin{tabular}{ll}
\hline Analisis Data & Prestasi Belajar Siswa \\
\hline Mean & 82,75 \\
Median & 82,90 \\
Modus & 84,95 \\
Standar Deviasi & 2,51 \\
\hline
\end{tabular}

Dari tabel diatas didapat bahwa rata-rata (mean) prestasi belajar siswa yaitu 82,75 , sedang nilai tengah (median) sebesar 82,90, dan nilai yang sering muncul (modus) yaitu 84,95, serta nilai standar deviasinya adalah 2,51 .

\section{Pembahasan}

Penelitian ini bertujuan mengetahui pengaruh intensitas penggunaan media sosial terhadap prestasi belajar siswa kelas X di SMA Muhammadiyah 1 Palangka Raya. Pengumpulan data dikumpulkan menggunakan angket, dari data angket intensitas penggunaan media sosial diperoleh nilai terendah yaitu 42 dan nilai tertinggi yaitu 134. Sedangkan untuk prestasi belajar siswa nilai terendah yaitu 71 dan tertinggi yaitu 100. Adapaun populasi penelitian berjumlah 145 siswa dengan sampel yang digunakan adalah 60 siswa dengan mengunakakn simple random sampling.

Dari hasil perhitungan berdasarkan tabel analisis data untuk intensitas penggunaan media sosial dengan jumlah siswa yaitu 60 siswa maka diperoleh nilai mean (rata-rata) 92,82 nilai ini menunjukan intensitas penggunaan media sosial adalah sedang, nilai median (nilai tengah) 74,78 nilai ini menunjukan intensitas penggunaan media sosial adalah sedang, nilai modus (nilai yang sering muncul) 78,78 nilai ini menunjukan intensitas penggunaan media sosial adalah sedang, dan standar deviasi 5,18 nilai ini menunjukan penyimpangan intensitas penggunaan media sosial adalah rendah. Berdasarkan perhitungan deskripsi frekuensi data untuk intensitas penggunaan media sosial masuk pada kategori rendah sebanyak 18 siswa atau 30\%, kategori sedang sebanyak 16 siswa atau 27\%, dan kategori tinggi sebanyak 26 siswa atau $43 \%$. Dari data tersebut menunjukan siswa yang menjadi sampel dalam Intensitas penggunaan media sosial berada pada kategori tinggi.

Dari hasil perhitungan berdasarkan tabel analisis data untuk prestasi belajar siswa dengan jumlah yaitu 60 siswa maka diperoleh nilai mean (rata-rata) 82,75 nilai ini menunjukan prestasi belajar siswa adalah sedang, nilai median (nilai tengah) 82,90 nilai ini menunjukan prestasi belajar siswa adalah sedang, nilai modus (nilai yang sering muncul) 84,95 nilai ini menunjukan prestasi belajar siswa adalah sedang, dan standar deviasi 2,51 nilai ini menunjukan penyimpangan prestasi belajar siswa 
adalah rendah. Berdasarkan perhitungan deskripsi frekuensi data untuk prestasi belajar siswa masuk pada kategori rendah sebanyak sebanyak 7 siswa atau 12\%, kategori sedang sebanyak 53 siswa atau $88 \%$, dan kategori tinggi sebanyak 0 siswa atau $0 \%$. Dari data tersebut menunjukan siswa yang menjadi sampel dalam prestasi belajar siswa berada pada kategori sedang.

Dari Hail uji normalitas liliefors serta bantuan program SPSS versi 20 maka didapat nilai untuk variabel intensitas penggunaan media sosial yaitu nilai sig sebesar $0,200>0,05$ sedang untuk variabel prestasi belajar siswa didapat nilai sig sebesar $0,200>0,05$. Dapat disimpulkan bahwa sampel dari kedua variabel berdstribusi normal. Berdasarkan hasil uji hipotesis menggunakan rumus product moment yang terdapat dalam SPSS versi 20 untuk intensitas penggunaan media sosial dan prestasi belajar siswa didapat koefisien korelasi rxy sebesar 0,211 dan signifikansi 0,105 >0,05. Hal tersebut menunjukan ada pengaruh intensitas penggunaan media sosial terhadap prestasi belajar siswa kelas $\mathrm{X}$ di SMA Muhammadiyah 1 Palangka Raya. Dari uji hipotesis product moment tersebut menunjukan ada pengaruh signifikan intensitas penggunaan media sosial terhadap prestasi belajar siswa kelas $\mathrm{X}$ di SMA Muhammadiyah 1 Palangka Raya adalah rendah dengan koefisien korelasi yaitu 0,211.

Intensitas penggunaan media sosial termasuk dalam kategori tinggi hal tersebut bisa disebabkan adanya fasilitas berupa smarthphone yang dimiliki oleh hampir semua siswa, kebutuhan akan informasi seputar pelajaran yang banyak tersedia di media sosial sehingga siswa akan ketergantugan dengan media sosial untuk mencari informasi, siswa mencari hiburan untuk menghilangkan kepenatan belajar, pengawasan guru terhadap siswa dalam menggunakan media sosial saat berada disekolah, rasa bosan saat mengikuti pembelajaran yang menurut siswa tidak menarik sehingga siswa mencari hiburan dengan menggunakan media sosial, pengawasan orang tua terhadap anak dalam menggunakan media sosial saat berada dirumah, serta keingginan siswa untuk menambah jaringan pertemanan yang lebih luas dengan bantuan media sosial. Media sosial dapat mempengaruhi prestasi belajar siswa disebabkan media sosial telah menjadi sarana bagi siswa dalam mencari referensi pembelajaran , media sosial sebagai sarana pertukaran informasi seputar pembelajaran sehingga siswa bisa belajar mandiri, masuknya informasi terbaru dari berbagai media sosial yang ada dalam smarthphone sehingga siswa bisa selalu mengetahui informasi terbaru, serta mudah mengakses bahan ajar yang ada dalam media sosial terutama bagi siswa yang malas membuka buku atau catatan pelajaran.

Namun ada hal lain yang mempengaruhi prestasi belajar siwa yaitu gaya belajar masing-masing siswa, ada siswa dengan gaya belajar visual, siswa dengan gaya belajar auditif dan siswa dengan gaya belajar kinestetik. Dari ketiga gaya belajar tersebut masing-masing siswa tentu mempunyai salah satu kecendrungan dalam gaya belajar, adapun gaya belajar menurut Deporter \& Henarcki dalam (Dirman dan Juarsih 2014) menyatakan "Siswa yang bergaya belajar visual, yang memegang peranan penting adalah mata/penglihatan (visual), mereka cenderung belajar melalui apa yang mereka lihat. Siswa yang bertipe auditif mengandalkan kesuksesan belajarnya melalui telinga (alat pendengarannya). Siswa yang memiliki gaya belajar kinestetik cenderung berbicara dengan perlahan, menanggapi perhatian fisik yang di tujukan ke mereka dan menyentuh orang lain untuk mendapatkan perhatian". Dari pembahasan menunjukan bahwa semakin tinggi intensitas penggunaan media sosial maka akan berpengaruh pada prestasi belajar siswa. Dari uji hipotesis product moment tersebut menunjukan ada pengaruh signifikan intensitas penggunaan media sosial terhadap prestasi belajar siswa kelas $\mathrm{X}$ di SMA Muhammadiyah 1 Palangka Raya yaitu rendah ditunjukan dengan nilai koefisien korelasi yaitu sebesar 0,211 .

\section{KESIMPULAN}

Adapun kesimpulan dalam penelitian ini sebagai berikut:

1. Intensitas penggunaan media sosial oleh siswa kelas X di SMA Muhammadiyah 1 Palangka Raya adalah sedang ditunjukan oleh nilai mean (rata-rata) 92,82, nilai median (nilai tengah) 74,78, nilai modus (nilai yang sering muncul) 78,78, standar deviasi 5,18. Masuk dalam kategori rendah 
sebanyak 18 siswa atau 30\%, kategori sedang sebanyak 16 siswa atau 27\%, dan kategori tingi sebanyak 26 siswa atau $43 \%$.

2. Prestasi belajar siswa kelas $\mathrm{X}$ di SMA Muhammadiyah 1 Palangka Raya adalah sedang ditunjukan oleh nilai mean (rata-rata) 82,75 , nilai median (nilai tengah) 82,90 , nilai modus (nilai yang sering muncul) 84,95, standar deviasi 2,51. Masuk dalam kategori rendah sebanyak 7 siswa atau $12 \%$, kategori sedang sebanyak 53 siswa atau 88\%, dan kategori tingi sebanyak 0 siswa atau $0 \%$.

3. Ada pengaruh intensitas penggunaan media sosial terhadap prestasi belajar siswa kelas X di SMA Muhammadiyah 1 Palangka Raya. Dengan koefisien korelasi sebesar 0,211 hal ini menunjukan pengaruh intensitas penggunaan media sosial terhadap prestasi belajar siswa kelas $\mathrm{X}$ di SMA Muhammadiyah 1 Palangka Raya adalah rendah.

\section{DAFTAR PUSTAKA}

[1] Arikunto, Suharsimi. 2002. Prosedur Penelitian: Suatu Pendekatan Praktek. Jakarta: Rineka Cipta.

[2] Asmaya, Fela. 2015. "Pengaruh Penggunaan Media Sosial Facebook Terhadap Perilaku Prososial Remaja Di Kenagarian Koto Bangun.” Jom Fisip.

[3] Caplin, James P. 2009. "Kamus Lengkap Psikologi.” P. 254 in. Jakarta: Rajawali Pers.

[4] Chaidar, Husain. 2014. "Pemanfaatan Teknologi Informasi Dan Komunikasi Dalam Pembelajaran Di SMA Muhammadiyah Tarakan.” Jurnal Kebijakan Dan Pengembangan Pendidikan 2(2):184-92.

[5] Dirman dan Juarsih. 2014. Teori Belajar Dan Prinsip-Prinsip Pembelajaran Yang Mendidik. Jakarta: Rineka Cipta.

[6] Hamdani. 2011. Strategi Belajar Mengajar. Bandung: Pustaka Setia.

[7] Masidjo, Ign. 2007. Penilaian Pencapaian Hasil Belajar Siswa Di Sekolah. Yogyakarta: Kanisius.

[8] Nasrullah, Rulli. 2012. Media Sosial Perspektif Komunikasi, Budaya, Dan Sosioteknologi. Jakarta: Simbiosa Rekatama Media.

[9] Pusat Bahasa Kemdikbud. 2016. "Kamus Besar Bahasa Indonesia Edisi Kelima (KBBI V)." Badan Pengembangan Dan Pembinaan Bahasa, Kementerian Pendidikan Dan Kebudayaan Republik Indonesia.

[10] Republik Indonesia. 2003. UU No 20 Tahun 2003 Tentang Sistem Pendidikan Nasional Pada Pasal.

[11] Rismana, Aida, Ellyn Normelani, and Sidharta Adyatma. 2016. "Pengaruh Jejaring Sosial Terhadap Motivasi Belajar Siswa-Siswi Sekolah Menengah Pertama (SMP) Di Kecamatan Banjarmasin Barat." Jurnal Pendidikan Geografi 3(5):38-50.

[12] Setiawan, Ebta. 2019. "Kamus Besar Bahasa Indonesia (KBBI) Kamus Versi Online/Daring (Dalam Jaringan)." Badan Pengembangan Dan Pembinaan Bahasa (Pusat Bahasa).

[13] Sugiyono. 2019. Metode Penelitian Kuantitatif, Kualitatif Dan R \&amp; D. Bandung: Alfa Beta.

[14] Susanto, Ahmad. 2013. Teori Belajar Dan Pembelajaran Di Sekolah Dasar. Jakarta: Prenada Media Group.

[15] Yunita, R., \& Menrisal, M. (2017). Pengaruh Penerapan Metode Pembelajaran Improve Terhadap Hasil Belajar Siswa Mata Pelajaran Teknologi Informasi dan Komunikasi (TIK)(Studi Kasus Kelas XI SMAN 12 Padang). Ristekdik: Jurnal Bimbingan dan Konseling, 2(1).

[16]Zarella, Dan. 2010. The Social Media Marketing Book. Jakarta: Serambi Ilmu Semesta.' 